\title{
DNA in Antiquity: Revisiting Jesus's Birth
}

\author{
Andries G. van Aarde \\ University of Pretoria
}

\begin{abstract}
In order to be born fully human (Latin: vere homo) $\mathrm{X}$ and $\mathrm{Y}$ chromosomes are needed. Without the involvement of chromosomes, Jesus of Nazareth would have had no ties to humanity. Aristotelian ("On the generation of animals" / "Peri zōōn geneseōs") and ancient Hellenistic (Galen on the Hippocratic Corpus) views on how the vere homo came into being differ much from today's knowledge of biology. In the Hebrew Scriptures, rabbinic traditions and GraecoRoman literature, vere homo was the result not only of a male and female contribution; the third component was divine involvement. This article revisits the textual evidence of the conception of Jesus in the New Testament. The results are compared to propositions in the Athanasian Creed (Quicunque Vult) and the exegetical and/or dogmatic/socio-cultural views of Friedrich Schleiermacher, Karl Barth and Rudolf Bultmann. The article explores the ethical and cultural relevance of the Christian belief that Jesus was both vere homo and vere Deus, and enters into critical discussion with British New Testament scholar Andrew Lincoln and his idea of "DNA in antiquity."1
\end{abstract}

\section{Key Terms}

Jesus's birth; Deoxyribonucleic acid (DNA); Hippocratic Corpus; divinity of Jesus; Jesus's humanness; NT evidence; Ignatius; Athanasius; F. Schleiermacher; K. Barth; R. Bultmann; A. Lincoln

\section{A Quote as Starting-Point}

I wrote this article for myself, to celebrate my 65 th birthday and the 50th anniversary of the New Testament Society of Southern Africa's journal

\footnotetext{
1 This article was initially presented at the NTSSA section Gender and Human Sexuality \& Jesus and the Gospels subgroups, at the Joint Conference of South African scholarly societies, University of Pretoria, 11-15 July 2016.
}

Neotestamentica 50.3 (2016) Special Edition 29-58

(C) New Testament Society of Southern Africa 
Neotestamentica in 2016. It begins with a quote. The quote refers to South Africa's most laureated novelist André Brink who wrote his 17th novel Praying Mantis (Bidsprinkaan) to celebrate his 70th birthday in 2005-the year of my retirement from a 25 -year active teaching position. It reads as follows (Brink 2006):

Cupido Cockroach was not born from his mother's body in the usual way. He is hatched from the stories told about him. In one story, he is abandoned in his mother's hut, with the umbilical cord still attached, by a stranger; in the next he is dropped from the sky by an eagle. He dies the day he is born, only to resurrect himself: at the moment of burial, the gathered Khoi find perched upon the lifeless little bundle a mantis in fervent prayer. From now on, at every significant turn in his life, it will reappear, "standing high on its hind legs, its front legs folded in devotion, in a green so intense it makes the eyes dazzle." ${ }^{2}$ (p. 3)

\section{Texts Producing Heretics}

Brink is known for his fictional histories of South Africa's past, based on in-depth research. He died on 6 February 2015 high up in the skies above Africa during a return flight from Europe, aged 79. His novel Praying Mantis is called magical realism (Anker 2008, 5). Like many of his other novels, for example The Chain of Voices (Houd-den-bek) in which Brink ([1982] 2007) narrates slave rebellion in the Cape in 1825 (Lenta 2010, 95-110), the origins of the emplotted "fictional history" in Praying Mantis is that of "racial tension in the shadowlands between myth and history" (back dust cover). The protagonist is Cupido Cockroach (in Dutch: Kakkerlak), living in the Cape Colony around 1760-1820. In an interview in London in 2005 Brink said he became aware of Cupido as a historical figure in 1980 and was "struck by the incredible exuberance of his name" (Brown [2005] 2016). In Augustan Rome the mythical figure Cupido is often portrayed as the son of the goddess of love, Venus, and the god of war, Mars (see Rose 2005, 27-28). Cockroach (Kakkerlak) is an insect classified as pest. What a contradictio in terminis! Cupido Cockroach was the first Christian missionary with KhoiSan origins. At the end of his life he was abandoned by his colonial "mentors" and the imperial-minded missionaries of the London Missionary Society. In Brink's narration

\footnotetext{
2 See Harrison's (2016) review of Praying Mantis by André Brink.
} 
Cupido returned to his roots and re-embraced Khoi mythology before he died in the deserted Kalahari at the mission outpost Nokaneng (today's Dithakong) in the North-Western Cape (Malherbe 1979, 377). An engaged and existential understanding of the interconnectedness of myth and history in the retelling of the birth and death of South Africa's first indigenous missionary can help us to also embrace the birth stories of Jesus of Nazareth retold in early Christian texts. However, Eurocentric modernism and rationalism seem to remain an obstacle. According to Horsley $(1989,18-19)$, in order to engage with the elements legend, myth and history in the stories of Jesus's birth (cf. Freed 2001, 16-17), it is necessary to understand these narratives "against the historical background of [their] origin and reference." He proposes a "concept of realistic or history-like narrative" as key to unlock their intent. So do I.

However, in South Africa my work on the birth and fatherlessness of Jesus has often been branded heretical (see references in Van Aarde 2013, 1-2 nn. 2 and 4). The time has come for me to revisit the birth of Jesus. British NT scholar Andrew Lincoln's (2014, 42-49) recent work on "Jesus's DNA," described in his article "How Babies Were Made in Jesus' Time," has prompted me to ask whether I should reinterpret my earlier understanding. In Lincoln's (2013) more comprehensive work, Born of a Virgin? Reconceiving Jesus in the Bible, Tradition, and Theology, he writes:

On ancient views of procreation and conception, human substance was supplied simply in the contribution of a mother's womb to the process, to which the male seed added the necessary animating principle. We now, of course, consider both parents' contributions to be necessary for human DNA [Deoxyribonucleic acid], with, in the case of a male, the mother providing the $\mathrm{X}$ chromosome and the father the Y chromosome. Ironically, while on ancient views the virginal conception could be employed to safeguard the humanity of Jesus over against docetic views of his nature, in light of contemporary biological understanding a virginal conception undermines the notion of Jesus sharing fully in our humanity and introduces a docetic element into the doctrine of the incarnation. Without complete human DNA Jesus would be a semi-divine or wholly divine special creation that appeared to be human. (p. 9)

My reflection on Jesus's birth has been based on an association of a historical-critical and a social-psychological reading of the relevant 
ancient texts (see Van Aarde 2004, 223-246). My exegesis concurs with historical scholarship in almost all major points. One of the very first historical-critical discussions stems from one of the most inventive publications produced in the 19th century, namely that of Friedrich Schleiermacher, in his romantic-style work, Die Weihnachtsfeier: Ein Gespräch ([1806] 1826), patterned after Plato's Symposium, and in English translated as Christmas Eve Celebration: A Dialogue (2010). In this "Christmas story," in the form of a celebration dinner by a familychildren and their parents together with an inner and outer circle of female and male friends, eating, drinking and singing-a representation of interpretations is skilfully portrayed through dialogue (Gespräch), either reasonably strung together or astutely untied from a spiritual (geistliche) cord. The rationalistically-minded lawyer, Leonhardt, churchless but not spiritless, remarks the following on the "meaning of Christmas" (Schleiermacher 2010, 69 n. 25):

Thus, it is obvious that the birth and the actual presence of Christ in history coheres very little with Christianity itself. Yet, that we know all too little about him, it might almost be said, bears just as little certitude, for already at the time when the first reports of him were composed, the opinions were so varied that the authors appear to have taken no notice of how these opinions were themselves to a certain extent changed from witnesses and reporters among the various parties. Indeed, it can be said that every report and every claim undoes the others.

In the NT there are two incompatible tenets regarding Jesus's birth, with variations in each. In the second century $\mathrm{CE}$ these two exclusive views were harmonised. This harmonisation was incorporated in the Nicene (4th century) and Athanasian (6th century) Creeds. However, reception-aesthetically seen, not all harmonisations are exegetically unsound. At the end of this article I will therefore conclude with a remark by Schleiermacher's rationalistic Leonhardt-character-a remark that witnesses a rich spiritual understanding of Jesus's birth, which coheres with the cord of both biblical and creedal discourse.

To a particular extent my previous work provides the foundation of the major content of this article. My claimed result of the revisiting of the topic is that my previous disposition still stands. Yet Lincoln's discussion of Jesus's DNA in relation to Jesus's full humanity has prompted further thought. I would now like to relate my perspective on the fatherlessness of 
Jesus (that had been judged heretical by some) more explicitly to creedal Christianity's emphasis on Jesus's vere homo and to the importance of Jesus's humanity for contemporary Christology and ethics. In this article, I firstly provide a brief review of the NT and early Christian textual evidence regarding Jesus's birth, and then the essence of Friedrich Schleiermacher's, Karl Barth's and Rudolf Bultmann's understanding of this evidence. Secondly, I enter into a critical discussion with Lincoln. Thirdly, the Athanasian Creed's formulation of the humanity of Jesus is reaffirmed. The article explores the ethical and cultural relevance of the Christian assertion that Jesus is both vere homo and vere Deus. The aim is to argue that indifference with regard to Jesus's humanness could enhance a religious and cultural discourse that would not be conducive to authentic existence inspired by Jesus's emancipatory being.

\section{Textual Evidence from Early Christianity}

I do not separate early Christian witness as consisting of so-called legitimately biblical on the one hand and illegitimately post-biblical evidence on the other hand. I see rather a Wirkungsgeschichte consisting of a trajectory in which an important theme is communicated by means of diversified reports but strung together into a harmonised cord. I divide the relevant textual evidence into three different categories: virginal conception, kenosis, and creedal Christianity. The following texts illustrate this diversity.

Virginal conception

\section{Luke $1: 31,35 ; 2: 7 a$}

[The angel Gabriel says to Mary:] "Take note, you will conceive and will give birth to a son ..." And the angel replied to Mary: "A holy spirit will overcome you and a power of the Highest will overshadow you; therefore, he who is born will be called holy, a son of God ...," and she gave birth to her son, the first-born.

\section{Matthew 1:20-21, 23-25}

[A]n angel of the Lord appeared in a dream to Joseph and said: "Joseph, son of David, do not hesitate to accept Mary as your wife, because she conceived due to a spirit that is holy and will give birth to a son and you will call him Iesous, since he is the one who will deliver his people from their wrongs ..." [This is how the words of the prophet will be fulfilled:] take note, a virgin will 
conceive and give birth to a son and he will be called Emmanouel, that is: God is with us. When Joseph awoke from his dream he did as the angel of the Lord had said and accepted his wife. He did not have intercourse with her until she had given birth to a son, and he called him Iesous.

\section{Kenosis}

\section{Galatians 4:4}

And when the time had come, God sent forth God's son, he who was born from a woman, [that is] he who was born under the law, in order to redeem those under the law so that we be adopted as God's children. ${ }^{3}$

\section{Philippians 2:6, 7}

He who had the form of God ... emptied himself by taking on the form of a slave by being born in the likeness of humankind.

\section{Creedal Christianity}

\section{John 1:1, 14}

[A]nd the Word was with God and God was the Word ... and the Word became creature-like ${ }^{4}$ and dwelt among us... and we beheld his glory.

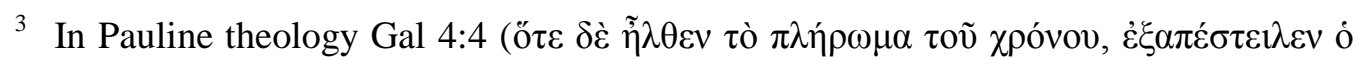

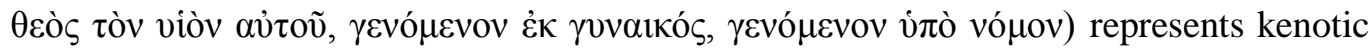
Christology and should be read in the same vein as other Pauline texts such as Phil 2:7b; 2 Cor 4:4; 5:21 and Rom 8:3 (see Hahn 2005, 208-209). Hahn (2005) puts it as follows:

$\mathrm{Da}$ Paulus sie [Gal 4:4] unter Voraussetzung des Präexistenzgedankens übernommen hat, zeigt die eigenständige Rezeption in Röm 8,3: "Gott sandte seinen

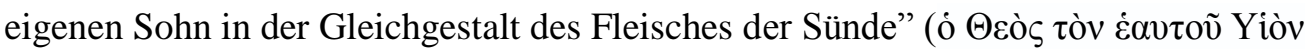

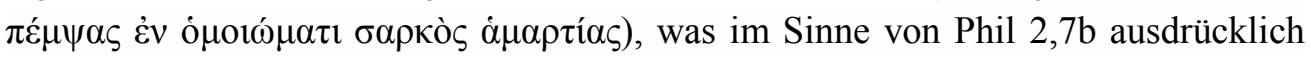
auf die Menschwerdung des Präexistenten bezogen ist...; einerseits steht dieses Gleichwerden unter der Voraussetzung der Selbstentäußerung [self-denial] bzw. der göttlichen Sendung, andererseits ist dabei die bleibende Bindung an Gott und damit die Sündlosigkeit vorausgesetzt, die in 2 Kor 5,21 ausdrücklich hervorgehoben wird ( òv $\mu$ 门̀ $\gamma v o ́ v \tau \alpha \dot{\alpha} \mu \alpha \rho \tau i ́ \alpha v)$. (p. 208; my emphasis)

4 The expression "creature-like" does not denote an entity less human. I would not like to use the term "flesh" because of two reasons: the one is the archaic connotation for humankind as "flesh"; the other is the outdated patristic debate whether the incarnation should be understood as either "enfleshment" in terms of the so-called "Logos/sarx model" or "ensomatosis" as "embodiment" in terms of the "Logos/soma model" (see Pearson 2003, 351 n. 6). 
Ignatius, Ephesians 19:1

[Our Lord] is truly of the seed of David according to the will and power of God ... truly born of a virgin ..., truly under Pontius Pilate and Herod the tetrarch, nailed [to the cross] for us in his flesh. (Roberts and Donaldson 1994, 57)

Ignatius, Smyrnaeans 1:1

Glorify God, even Jesus Christ, who has given you such wisdom. For I have observed that you are perfected in an immoveable faith, as if you were nailed to the cross of our Lord Jesus Christ, both in the flesh and in the spirit, and are established in love through the blood of Christ, being fully persuaded with respect to our Lord, that he was truly of the seed of David according to the flesh, [Romans 1:3] and the Son of God according to the will and power of God; that he was truly born of a virgin, was baptized by John, in order that all righteousness might be fulfilled [Matthew 3:15] by him; and was truly, under Pontius Pilate and Herod the tetrarch, nailed [to the cross] for us in his flesh. Of this fruit we are by his divinely-blessed passion, that he might set up a standard [Isaiah 5:26, Isaiah 49:22] for all ages, through his resurrection, to all his holy and faithful [followers], whether among Jews or Gentiles, in the one body of his church. (Knight 2009)

Athanasian Creed (Quicunque Vult = "Whosoever wishes") 2932

He therefore that will be saved: must thus think of the Trinity.

Furthermore it is necessary to everlasting salvation: that he also believe rightly the Incarnation of our Lord Jesus Christ.

For the right Faith is that we believe and confess: that our Lord Jesus Christ, the Son of God, is God and Man;

God, of the Substance of the Father, begotten before the worlds: and Man, of the Substance of his Mother, born in the world;

Perfect God, and Perfect Man: of a reasonable soul and human flesh subsisting;

Equal to the Father, as touching his Godhead: and inferior to the Father, as touching his Manhood.

Who although he be God and Man: yet he is not two, but one Christ; One, not by conversion of the Godhead into flesh: but by taking of the Manhood into God; (Unus autem non conversione 
divinitatis in carnem, sed assumptione humanitatis in Deum. $)^{5}$ One altogether, not by confusion of Substance: but by unity of Person. ${ }^{6}$

Despite incompatibility and divergence, a thread binds the NT textual evidence and the Christian creeds. This thread is not the propaganda that Jesus, son of God, is truly divine. Rather it is that this divine figure is human and humane - not just perceived, but genuinely so. However, Lincoln's contribution prompts renewed reflection.

The birth of Jesus is narrated in the gospels of Matthew and Luke. Matthew's version relates to the OT (Septuagint) and pseudepigrapha (e.g., the birth narrative of Moses in Pseudo-Philo's Liber antiquitatum biblicarum). Matthew plays on words: "messiah"/"Moses" and "Yehoshua"/"Yeshua"/“Jesus" (YHWH delivers), and makes use of apocalyptic-messianic themes. One such theme is that Israel's messiah is the coming Son of Man who will inaugurate the perfect kingdom of God. This can be called "the Christianising of Jesus" (German: Christianisierung). Jesus is exalted with honorific titles (in German: Würdeprädikationen). Luke also honoured Jesus with titles such as "saviour" (ó $\sigma \omega \tau \eta ́ \rho)$. He utilises propaganda motifs from Graeco-Roman stories about deities and the emperor cult (cf. Miller 2003, 133-153).

Since Constantine (4th century CE), classical ontological Christology was developed by means of complicated Graeco-philosophical metaphysics and Roman legal terminology. Terms such as persona and substantia derive from the Roman legal system. Individuals could share

5 See later for Schleiermacher's endorsement of Athanasius (and of John of Damascus) (see Pearson 2003, 351) who believe that through Jesus's persistent and permanent God-consciousness (assumptionis humanitas in Deum) he in his historical person became the Urbild and the Vorbild (archetype) for all believers' assumption of God in their inner beings (see Oseka 2015, 40) and that this God-consciousness and dependence on the Absolute constitute the essence of Christ's salvific act.

${ }^{6}$ Sed necessarium est ad aeternam salutem, ut incarnationem quoque Domini nostri Iesu Christi fideliter credat. Est ergo fides recta ut credamus et confiteamur, quia Dominus noster Iesus Christus, Dei Filius, Deus [pariter] et homo est. Deus [est] ex substantia Patris ante saecula genitus: et homo est ex substantia matris in saeculo natus. Perfectus Deus, perfectus homo: ex anima rationali et humana carne subsistens. Aequalis Patri secundum divinitatem: minor Patre secundum humanitatem. Qui licet Deus sit et homo, non duo tamen, sed unus est Christus. Unus autem non conversione divinitatis in carnem, sed assumptione humanitatis in Deum. Unus omnino, non confusione substantiae, sed unitate personae (Archbishops' Council of the Church of England 2015). 
some substance with another while retaining the ownership of their material possessions/attributes. From this the monotheistic dogma of the One Triune God (God Three-in-One) was developed. Sharing the same substance of being, three persons feature different aspects of the divine economics of salvation: begetting and providing (God the Father), conciliating (God the Son), managing (God the Holy Ghost).

With regard to the second category, God the Son, dogmatics focused on the two natures of the Son: divine and human. Since Plato (ca. 427-347 BCE), metaphysics was about the distinction and relationship between "natural" (human-like) and "supernatural" (God-like). Christian theologians (since the 9th century) focused on matters of God rather than humanity. This "Christology from above" emphasised the similarity of being in the personae of the Trinity.

Later NT scholarship referred to the "Christologies" of NT authors as "functional." The focus was on Jesus's behaviour. This is "Christology from below." Today there is a third perspective: "Christology from the side." It is not about the relationship between "God-like" and "humanlike" in Jesus, nor about how his later followers interpreted his words and deeds, but rather about how Jesus's contemporaries experienced him. After his death Jesus's followers saw him as God's Messiah, foretold by the prophets, who would inaugurate a dispensation of righteousness. They venerated him with names borrowed from Israel's Scriptures and the surrounding world.

Those for whom Jesus was not the "messiah" opposed this veneration (apotheosis) and defamed him and his followers. Probably in response to accusations of illegitimacy, Matthew explained that Jesus's birth was the result of an intervention by God. Luke ostensibly also knew of the illegitimacy charge in response to which he combined the claim of Jesus's messianic origin with the tradition of the "newborn baby." This combination was common in Graeco-Roman deification (apotheosis) and emperor-cult motives. For the earliest Christ-followers in Jerusalem before its destruction by the Romans in $70 \mathrm{CE}$ Jesus was "messiah"/"son of David" who was adopted as the "son of God." This was not interpreted in terms of a divine conception. It ought also not to be literalistically understood, that is, that "son of ..." refers biologically to Davidic lineage. However, theologically seen, it could be assumed that "son of David" was used as an expression of descent. For messianists "son of David" or "seed of David" are simply exchangeable for "messiah." The same is true for Paul and Mark. The cry of the blind Bartimaeus in Mark 10:47, Yì̀ $\Delta \alpha v i \delta$ 


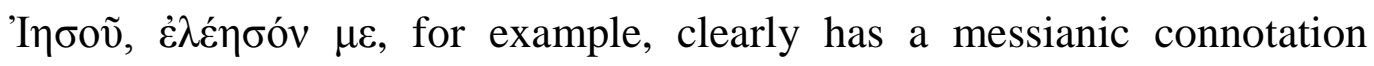
(Duling 2012, 91-119).

For Lincoln, on the other hand, this terminology "seed of David" is a claim to patrilineal (biological) descent from David through to Joseph, the father of Jesus. To Lincoln, "seed of David" has this meaning whether we find the expression in Luke-Acts, Paul, Hebrews, or the Johannine literature (Lincoln 2013, 26-33). I beg to differ in light of the overlap of meaning in Paul's thinking between the word $\sigma \alpha ́ \rho \xi$ with "son of David" or "seed of David" and $\pi v \varepsilon \tilde{v} \mu \alpha$ with "son of God." For Paul the ethos of

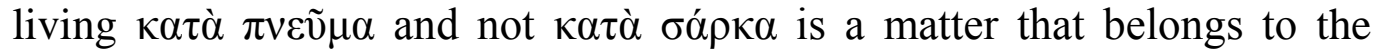
sphere of confessional/creedal language and not to that of anatomical/ biological language. ${ }^{7}$ Jewett $(2007,103-104)$ also sees Rom 1:3-4 as a citation "from an early Christian creed... originated as a pre-Pauline expression of Jewish Christian theology." " Neither the use of "seed" nor

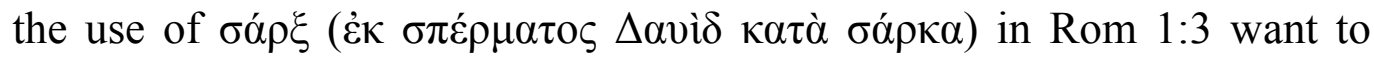
emphasise biological descent. The terms rather highlight two ways of existence according to two aeons: the perishable human existence and the sphere of divine existence (see Jewett 2007, 103-106). With regard to Paul's usage Schweitzer $(1985,1004)$ says:

In Rom. 1:3-4 Paul contrasts the sphere of sárx with that of heaven or pneuma. In this limited and provisional sphere Jesus is the Davidic Messiah, but the decisive thing comes in the sphere of the pneuma... [I]t indicates sphere rather than origin... The present aeon or cosmos may be equivalent to sárx (cf. 1 Cor. 2:6), but the real antithesis is between God and humanity... [Yet,]

\footnotetext{
7 Thus, the expression "seed of David" / "son of David" in Rom 1:3-4 and 2 Tim 2:8 is not related to the figure "Joseph, son of Jacob" to whom the infancy narratives in the Gospel tradition refer. Both Rom 1:3-4 and 2 Tim 2:8 bear witness to the fact that the post-Easter Christ-followers honoured Jesus of Nazareth as the Messiah. Bultmann $(1985,155)$ relates the expression "Christ according to the flesh" (2 Cor 5:16) to the other Pauline expressions in Phil 3:21. He further sees the reference to the

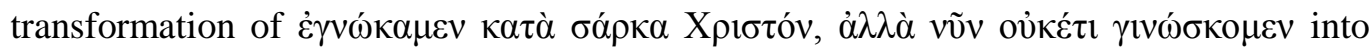

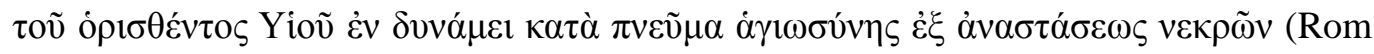
1:4) as belonging to the same referential sphere as the expressions $\tau$ ò $\sigma \tilde{\omega} \mu \alpha \tau \tilde{\eta} \varsigma \delta$ ó $\xi \eta \varsigma$

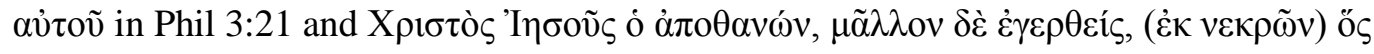

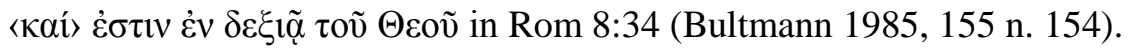

8 According to Jewett $(2007,104)$, the expression "seed of David" refers to the "popular Jewish expectation of a son of David," found in Pss. Sol. 17:21. The core of the "confession" is the Pauline "insertion [into the pre-Pauline creed] of the references to sárx [Rom 1:3d] and pneuma [Rom 1:4c]."
} 
God's promise is the opposite of sárx (Rom. 9:8). In Christ the divine sphere has invaded the human.

It is only in the work of post-NT "apologists" that $\sigma \alpha ́ \rho \xi$ became an important term for the incarnation (Schweitzer 1985, 1007) and the term "seed/son of David" as a biological reference to Christ's Davidic descent (cf. Ignatius, Eph. 20:2), which is by way of Jesus's mother (Ignatius, Eph. 18:2; Justin, Dial. 45.4). ${ }^{9}$

The earliest biblical tradition gives no indication of knowledge of Jesus's parentage, except for the suggestion of his "fatherlessness" and divine conception in Matthew and Luke. Divine conception resembles the birth of Moses in Pseudo-Philo's Liber antiquitatum biblicarum (9:1-10) (reflected in Matthew) (Harrington 1985, 317), and the conception of Perseus in Ovid's Metamorphoses (reflected in Luke) (Ovid [8 CE] 1997, 483-484). Jesus was depicted as the adopted grandson of either Jacob (Matt 1:16) or Eli (Luke 3:23), the father of Joseph. ${ }^{10}$ He was quickly labelled "son of Joseph" in response to allegations of illegitimacy. God exalted Joseph despite slander. ${ }^{11}$

Hellenistic Christ-followers conveyed the title "Son-of-God" on Jesus as part of their propaganda and apologetics. Son-of-god was a common idea in that culture and was then applied uniquely to Jesus, designating him as divine, filled with divine power (Bultmann 1968, 133). ${ }^{12}$ To Christ-followers from an Israelite background, the idea of a suffering messiah would have been offensive. To Christ-followers from a

9 See especially Matt 1:16 and Luke 3:23. In Matthew Joseph was not Jesus's biological father but is genealogically linked to Davidic descent. In Luke this "paradox" is explicitly spelled out: "Jesus ... being the son (as was supposed) of Joseph (⿳亠丷厂 viós, ஸ் દ̇ं

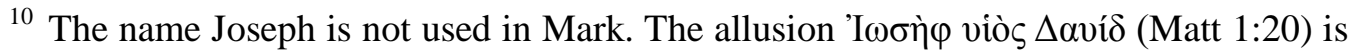
peculiar to Matthew.

${ }^{11}$ For an extensive discussion of a trajectory of textual references to the Joseph figure in biblical and extra-biblical sources, see Van Aarde (1998, 315-333).

${ }^{12}$ According to Mark (1:9-11), Jesus was shown to be Son-of-God when he was baptised and filled with the Spirit of God. Bultmann (see Aland and Aland [1981] 1992, 162) points out that this view can be found from the "Western" manuscript tradition of Luke 3:22 up to Augustine (inter alia, the Latin version of the 5th-century Codex Bezae Cantabrigiensis [Dit], Justine, Clement, and Latin documents by a number of Western church fathers). According to this tradition, a voice came from heaven that said, in the words of Ps 2:7: "You are my Son; today I have begotten you." In line with this way of thinking, Acts 2:22 recounts that "God made Jesus of Nazareth known to you through powerful deeds, through the miracles and signs that God let him do in your midst." 
Hellenistic background it was an "enigma," a mystery (see Ignatius, Eph. 19:1 and Smyrn. 1:1; Köstenberger, Kellum and Quarles 2009, 187). The divine origin and power of the Son-of-God would not have been belied by his humanness.

In Hellenistic culture a child could be conceived through sexual intercourse of a deity with a mortal human. Such offspring performed heroic acts and some were honoured in cults. Even ordinary people had a divine soul. Epictetus (Diatr. 2.8.12; also Marcus Aurelius and Plotinus) respected people with "good sense." Spiritual people could do miracles aided by the "god in them" (Harris 2008, 28 n. 38). Divinity and humanness also came together in the "son-of-god" saviour figures in the mystery religions. They suffered the human fate of death, but triumphed in resurrection. Worshippers partook in this victory through mystery rites.

The idea of Jesus as "Son-of-God" varied in Hellenistic Christianity, depending on which mythological tradition influenced it. The Synoptic Gospels were influenced by the Greek tradition: Jesus as the Sonof-God with divine authority. The "charisma" of the divine figure was attributed to the Divine Spirit. For Christ-followers influenced by Israelite thinking this was also the case with the "holy men of God" in the OT, such as David and the prophets.

In Eastern mythology Jesus was seen as the pre-existing Son-ofGod who became human. Paul and John took this as their point of departure. For them Jesus was not a miracle worker empowered by the Divine Spirit, as portrayed in the Synoptic Gospels. He was rather a "preexistent" divine figure who, through death and resurrection ("rebirth"), regained his original divinity. Both these types are represented in NT texts. They are mutually exclusive. According to the one Jesus was "born divine." His divinity began at birth. According to the other, Jesus emptied himself from the divine status he previously had, in order to become human, and then regained his divine status with the resurrection.

Post-NT Christian writings combined the two types, though Ignatius seems to have had some sense of the incompatibility of the "three enigmas" (Mary's virginity, her pregnancy, and the death of the Kyrios) with the "kenosis" concept (Schönborn 2010, 122).

On the periphery of the NT is a third type. The cosmos, because of its transience and corruption, could not possibly be the realm of the loving God (the Father of Jesus). The creator of the cosmos (witnessed to in the OT) should therefore be distinguished from the Father of Jesus. Adherents to this "gnostic" idea denied that God's son could take on human form. In 
his polemics against the "Gnostics," Ignatius (Eph. 19:1) combined all three types and this formed the basis of the dogma of the two natures (divine and human) of Jesus. As a result of the combination of two cultural traditions, he who proclaimed unmediated access to God now became the mediator. The iconoclast became a cultic icon. Funk (1996) formulates this complexity as follows:

The paradox of the dead god represents the marriage of the imageless tradition of Israel with the iconic mentality of the Graeco-Roman world. For descendents of Abraham, no one has ever seen God, and God cannot be pictured. For the Greeks, to consort with the gods was an everyday matter, and it was commonplace to make images of every imaginable deity. For hellenized Christians, Jesus the iconoclast became Christ the icon. Because Christianity has a twin heritage, its ancestors are both Jews and Greeks, it has never quite made up its mind whether it is iconic or iconoclast. (p. 44)

"Son-of-God" functioned in two spheres, that of divine origin and that of divine power. Divine origin pertains to the miraculous birth. In some traditions the mother would have been a virgin, for example Perseus born from the union of the virgin Danae and Zeus. In other traditions virginity did not feature, for example Coronis impregnated by Apollo. The child Asclepios was reared as a deified diviner and medicine-man. Hercules was born from the union of the married woman Alkmena and Jupiter. In both traditions the son-of-god performed heroic deeds and great benefactions (see Van Aarde 2001, 160).

The second, divine power, pertains to the pre-existent son-of-god who became human. His divine power manifested in his victory over death. This was the approach of Paul. After Paul, Mark's view was that of Jesus's adoption as "Son-of-God" through the work of the Spirit. Mark did not relate Jesus's status as "Son-of-God" to a divine birth. In Mark Jesus was declared Son-of-God at his baptism when he was filled with the Divine Spirit. Luke, who used Mark as a source, did relate Jesus's adoption as Son-of-God to the virginal conception through the Spirit.

For Matthew Jesus, filled with the Spirit, was the Messiah and apocalyptic Son of Man. Matthew related the "adoption as Son-of-God" theme to the marriage of Joseph and the impure pregnant Mary on the basis of a divine intervention. A similar motif is found in the pseudepigraphic document Joseph and Aseneth (Burchard 1965; 
Philonenko 1968; Standartinger 1995; 1996), ${ }^{13}$ dated between 100 BCE and 115 CE (cf. Chesnutt 1996, 286). In Johannine and Pauline literature, representatives of the second type, Jesus's "Sonship-of-God" is an anomaly, a paradox. A pre-existent figure, equal in status to God (cf. John 1:1-2), Jesus took the fate of humanness onto himself. By means of natural birth he became completely human (cf. Gal 4:4; John 1:14). Exactly in this apparent anomaly the divine redemptive events lie hidden. For human beings redemption means that they can share in Jesus as Sonof-God, can be reborn in the Spirit and can be called children of God. Paul puts forward a similar idea: in sharing in the fate and suffering of the preexistent Son-of-God, people can become adopted children of God.

Parallel stories of both types - miraculous birth and triumph over death - were well represented in the first century and both traditions were applied to Jesus. In early Christianity, Ignatius harmonised the two types and that became the foundation of "creedal Christianity." This is probably best expressed in the Athanasian Creed (see later).

\section{$4 \quad$ Three Readings of Jesus's Birth}

\subsection{Friedrich Schleiermacher's reading}

My reflection on Schleiermacher is short. However, his engaged and existential interpretation of Jesus's birth forms the platform from which I conclude this essay. More detail is therefore following. To understand the difference between his interpretation of Matthew's and Luke's birth stories of Jesus, on the one hand, and the Johannine version, on the other hand, one needs some insight into his sophisticated hermeneutics. In some sense Schleiermacher paved the way for Bultmann's hermeneutics in which a distinction is made between historisch and geschichtlich: "Under historisch, Bultmann understands the usual historical factualness of an event, while geschichtlich refers to the existential consequence of such an event" (Van Aarde 2014, 256; emphasis original). Schleiermacher

\footnotetext{
${ }^{13}$ Joseph and Aseneth is a story of a "holy marriage." In the shorter constructed version of Philonenko (1968) Sophia is replaced by the figure Metanoia (referring to Aseneth): "And Metanoia is a virgin, very beautiful and pure and chaste and gentle; and God Most High loves her, and all his angels do her reverence" (Jos. Asen. [Ph] 15:7-8; see Standartinger 1996, 309). In the longer constructed version (that of Burchard 1965) Sophia says: "(What a) foolish and bold (woman) I (am), because I have spoken with frankness and said that a man came into my chamber from heaven; and I did not know that (a) god came to me" (Jos. Asen. 17:9 [B]).
} 
distinguished between Chronik ("historisch") and Anschauung ("geschichtlich"). The first is investigated by means of a grammatical (technical) analysis ("historical criticism") and the latter by means of an existential ("divine") understanding ("psychological interpretation"). In another essay I put it as follows (Van Aarde 2015):

Schleiermacher used the divinatory as point of departure in his sophisticated hermeneutics. He believed the divinatory resulted from the astuteness of the interpreter, a talent which rarely occurs... Gifted interpreters, however, succeed in reexperiencing the spirit of ancient texts as if the gift of sound hermeneutics is granted... In this way [other less talented interpreters] also can experience a repeated enjoyment of the dynamics and wonder (Zauber) of bygone cultures (Schleiermacher 1927-1928/1985). The divinatory therefore consists of post-feeling, post-understanding, post-enjoyment, in the sense of re-experiencing life's psychological dynamics. (pp. 8-9)

With regard to the "history" of Jesus's birth, one can infer from Schleiermacher's hermeneutics that John is more talented than Matthew and Luke (see later). Tice (2011, 59 n. 96) comments on this "historical" disposition of Schleiermacher (my paraphrase): According to Schleiermacher, the retention [by the author in John's gospel] of past memory [of the authors of the Synoptics] entails a combination of "inner and outer features into a clear historical perspective" [in Schleiermacher's German: die Verknüpfung des Inneren und Äußern zu einer geschichtlichen Anschauung].

Exegetically speaking, therefore, Schleiermacher was sceptical towards the historical authenticity of the infancy narratives in the tradition in the Synoptic Gospels. However, this does not mean that he opposed "confessional subscription" (Schleiermacher 1821-1822, 147-148 [§30.1]). Oseka (2015) describes Schleiermacher’s view as follows:

Schleiermacher pointed out that the request, that the Bible must be explicated in such a way to suit the confessions, even if it obviously deviates from the historical and literary context of the Scripture, undermines the very principle out of which the Reformation was born ... [H]e realised that at the inception of the Reformation the creeds were not used as means of enslaving the 
exposition of the Scripture but rather as the temporal and provisional declarations of the biblical message. (pp. 58-59)

According to Pearson (2003, 351), Schleiermacher applauded the way in which John of Damascus ${ }^{14}$ and Athanasius interpreted the emphasis in the classical creeds on the relation between the human and the divine in Christ, but avoided "two-natures language." He understood Jesus's "emergence as the appearance of God's Son" as a presentation of the inborn inner nature of humankind to absorb the divine into itself (cf. Oseka 2015, 40). According to Schleiermacher, the belief of church fathers in Jesus's divinity expresses that Jesus was "permanently and staunchly conscious of his own dependence on the Absolute," and "[o]n that account, Jesus could be construed as the archetype of the perfect religious selfconsciousness which came true in his historical person." Jesus's salvific meaning pertains to the belief that humankind "can reach exactly the same perfect religious self-consciousness under his influence" (Oseka 2015, 40).

Prompted by the narratives about the Jesus of faith, Schleiermacher emphasised the importance of conversation, dialogue, criticism, joy, childlike faith and female consciousness with regard to faith in his Christmas celebration. For him the birth of Jesus was not central to "Christian faith," but rather the "perfection"_- "sinlessness" — of Jesus, to which the miraculous features in the birth stories attest. He links Jesus's lack of sin to his God-consciousness. When Christ-followers engage with the "dialogue of the Christmas celebration" (Van Aarde 2003; Schleiermacher 2010), they participate in Jesus's God-consciousness.

\footnotetext{
${ }^{14}$ See John of Damascus, (Exact Exposition of) the Orthodox Faith/De Fide Orthodoxa IV.4.20-28 (trans. F. H. Chase 1999, 338): "But, since He had shared with us what was better and we had not kept it [the assumption of God in us], He now takes His share of what is worse, of our nature. I mean to say, that through Himself and in Himself He may restore [us] to His image and what was to His likeness, while also teaching us the virtuous way of life which He has made easy of ascent for us through Him, and that, having become the first fruits of our resurrection, He may by the communication of life free us from death and restore the useless and worn-out vessel, and so that, having called us to the knowledge of God, He may redeem us from the tyranny of the Devil and by patience and humility teach us to overthrow the tyrant." In his recent book on the concept perichoresis (divine indwelling) in John of Damascus, Thombly $(2015,98)$ comments as follows with regard to the above quote: "The restoration of the image entailed assumption of full humanity, the transformation of the humanly assumed, and the communication of that transformed humanity."
} 


\subsection{Karl Barth's reading}

Jesus's birth is not a central tenet in Barth's dogmatics. However, he opposed Schleiermacher's view on "the God-consciousness in Jesus" and in his followers (Barth 1982). He also did not agree with his father, Fritz Barth (1918, 256-273), for whom the virgin conception of Jesus was neither relevant nor historical. Karl Barth thought that his notion of the "virgin birth" as a "sign" would be an acceptable response to the scepticism of modern exegetes (Resch 2012, 5). In his Die christliche Dogmatik, Barth $(1982,365)$ described the infancy narratives in the Gospels as Urgeschichte ("primal history"). This allows him to refer to Jesus's birth as an event that occurred in history, in a particular time and space, but an "event" that cannot be investigated historical-critically like other historical data. He admits that the orthodox church sees the miraculous conception of Jesus by the Spirit as a "historical fact." Yet, for Barth, Jesus's birth (similar to Jesus's resurrection) should not be understood alternatively as either göttliche Faktum or Nicht-Faktum. An explicit development in Barth's understanding of the "doctrine of the virgin birth" is to be identified (cf. Resch 2012, 37-82). In his Die kirchliche Dogmatik he departed from any discussion on the mythical nature of the infancy narratives and began to rely "theologically" on the Bible to emphasise the dogma of original sin (Barth 1982, 163-164, 372; Resch 2012, 43).

He proceeded from what he suggested in his Die Göttingen Dogmatik. For him Jesus's birth represents a miraculous sign that expresses the nature of divine revelation (Barth 1991, 138-239). The revelation of God means that God makes God known to humankind. By doing so Barth considered himself to be in alignment with creedal Christianity: by means of incarnation God is wholly God and fully human. God, who is concealed, allows through the incarnation of the Logos to become known. God is fully human, otherwise it would not be comprehensible for humankind to know God. Yet God and humankind are not mixed with each other through this union (see the Athanasian Creed).

However, to ignore biology is to evade early Christianity's combination of theology with biology. Moreover, such abstract dogmatic de-contextualises creedal Christianity's debate with "docetic Christianity" and becomes a docetism itself. Escaping the challenge of interpreting the biblical evidence on Jesus's humanness and humaneness is tantamount to sidestepping the present-day cultural discourse on human rights and 
human dignity. It fails to give emphasis to the relevance of religion for the cultural discourse.

\subsection{Rudolf Bultmann's reading}

In his historical analysis of the synoptic tradition Rudolf Bultmann (1972, $292,295,298,302,304,306)$ did not consider it a real possibility that the defamations about Jesus's alleged illegitimate birth were already present in Matthew's story. His opinion was that these allegations were evidence of the second-century polemics by Origen against the Greek philosopher Celsus. ${ }^{15}$ In his treatment of the infancy narratives, Bultmann never paid attention to the possibility that implicit apologetic features in these narratives could have a historical base in the life of Jesus. According to Bultmann (1972, 293-294), it is simply legendary material.

Bultmann's interest is much more in early Christianity's notion of Jesus's sinlessness, which is related to Jesus's baptism by John. Bultmann (1974, 26-27) says: “The account of Jesus' baptism (Mk. 1:9-11) is

${ }^{15}$ Origen, Cels. I.28. A similar slur can be found in the Talmud, e.g., Shabbat 104b. According to Kee (1990, 12-13), the references in the Talmud "are of uncertain date, since the basic documents of rabbinic Judaism were not produced until the period from the second to the sixth centuries.... Jesus is referred to as 'a certain person,' on the assumption that even to mention his name would be to give him undue honour." However, Kee points out that,

in some passages of this Jewish material, [Jesus] is called Ben Stadia or Ben Panthera, implying that he is the illegitimate son (Ben, in Hebrew) of a soldier or some other unworthy person. Similarly, his mother is pictured as disreputable. In a document known as Shabbath (104) the following incident is reported: "Rabbi Eliezer ... was arrested for Minuth [holding Christian beliefs] and they brought him to the tribunal for judgment. The governor said to him, 'Does an old man like you occupy himself with such things?' He said to him, 'Faithful is the judge concerning me.' The governor supposed that he was saying this of him, but he was not thinking of any but his Father who is in heaven. [The governor] said to him, 'Since I am trusted by you, I shall be the same concerning you ... Perhaps these societies [the Christians] err concerning these things. Dismissus, behold you are released.' And when he had been released from the tribunal, he was troubled because he had been arrested for Minuth. His disciples came to him to console him, but he would not take comfort. Rabbi Aquiba [early second century] came in and said to him, 'Perhaps one of the Minim [Christians] has said a word of Minuth and it pleased you.' He said, 'By heaven, once I was walking in Sepphoris, and I met Jacob of Chepat Sichnin, and he said to me a word of Minuth in the name of Jesus Ben Pantiri, and it pleased me. And I was arrested for words of Minuth because I overstepped the words of Torah [the Jewish law]: Keep your way far from her, and do not come near the door of her house, because she has cast down many wounded [Prv 5:8]."” 
legend, certain though it is that the legend started from the historical fact of Jesus' baptism by John." According to Bultmann (1974, 27), it is "told in the interest not of biography but of faith." And in his reconstruction of the Synoptic Tradition he says the same (Bultmann 1967, 263 n. 1):

Without disputing the historicity of Jesus' baptism by John, the story as we have it must be classified as legend. The miraculous moment is essential to it and its edifying purpose is clear. And indeed one may be at first inclined to regard it as a biographical legend; it tells a story of Jesus. ${ }^{16}$

Bultmann admits that Jesus underwent a "baptism of penitence" (in German: Bußtaufe) and says that Jesus did not need to do so. ${ }^{17}$

\section{$5 \quad$ Andrew Lincoln's Reading}

Lincoln's $(2014,44)$ insights into "DNA in antiquity" build on Laqueur's (1990, 4-8; Kessler 2009, 65-126) notion of the "one sex/flesh model." Laqueur pointed out that masculinity and femininity, according to the Hippocratic Corpus (Aristotle, On the generation of animals / Peri zōōn geneseōs 2.4.73b.20-23; Lincoln 2013, 256-257), do not differ essentially but rather hierarchically. Women and men's sexual organs differ in terms of anatomical perfection. Essentially women are "men" but retain their vital heat inside the body, which causes their "imperfection." Bodily fluids were also seen as essentially identical. Semen and milk are discharges that are various forms of blood. They vary because of the heat of the blood. Aristotle (in Van der Horst 1990, 287-302) regarded menstruation blood as impure sperm and Galen (Galenus [129-216 CE] 2003, 51-173), on account of the Hippocratic Corpus, therefore thought that women produce

\footnotetext{
${ }^{16}$ Bultmann (1967, 263 n. 1) uses the expression "Wirksamkeit Jesu" for "ministry." In The History of the Synoptic Tradition, Bultmann (1972, 247 n. 2), adds: "yet not that this linking must be made by the story of a baptism, or that it could only be made if the baptism of Jesus were not an actual historical fact."

${ }^{17}$ Seen from the perspectives in the Gospel of the Nazoreans and the Gospel of the Ebionites, Jesus's baptism by John was regarded as an embarrassment. According to Ernst (1989), Mark 1:9 states decisively that Jesus did come from Nazareth in Galilee to be baptised in the river Jordan. However, Ernst finds it strange that theologians have not given thought to what lies beyond this "clearly edited apologetics by the church." To him the church disputed the possibility that Jesus, son of God, could be connected with conversion and the forgiveness of sins. Bultmann seems to be indifferent with regard to the question why Jesus would want to be baptised.
} 
sperm, although impure in comparison to the sperm of men. Men's hardness and dryness were considered a better quality than female moistness and softness. For Aristotle (Gen. an. 764a12-20; see also the Hippocratic Corpus) the womb is an oven in which the seed of man is cooked till it ignites, creates life, and forms a substance. Substance is provided by the woman. Progeny is female when the seed is undercooked and therefore prevented from reaching its full capability (Dean-Jones 1994).

A similar view is found among the Israelites (Wis 7.1-2; 4 Macc 13.19-20; Lincoln 2013, 257). However, in the Hebrew Scriptures there are many references to conception where male seed does not play much of a role, but the emphasis is on God's contribution. Isaiah 44:2 states: "Thus says the Lord who made you, who formed you in the womb and will help you." Lincoln $(2014,46)$ puts it this way: "Yet what is significant about a number of the literary references to conception is that, as in the case of Job 31:19 and Psalm 139:16, it is simply God and the mother's womb with its unformed substance that are mentioned." According to Lincoln $(2014,46)$, "divine conception" in antiquity should not simply be interpreted metaphorically: "Ancient biology and Jewish theology were not kept in separate spheres-but intermingled." Three parties interact: "God, the male with his seed, and the female with the blood or fluids of her womband all three parties are understood to be actively involved in the production of a human foetus." Lincoln $(2014,48)$ is of the opinion that regarding Jesus's birth the Gospels "have taken the omission of the male one step further: They make Mary's womb a virginal one (cf. Matthew 1:23; Luke 1:34); she has never had intercourse." ${ }^{18}$ However, he considers the infancy narratives in the Gospels analogous to ancient biographies. They also witness "simultaneously two different stories about the origins of a great figure [e.g., Plutarch's contradicting biographies of Alexander the Great]. One recounted ordinary physical lineage. The other, suitable in the light of his later achievements, involved a miraculous conception and envisaged him as a son of the gods" (Lincoln 2014, 49). According to Lincoln (2013, 117-118), Luke upholds two contradicting, juxtaposing perspectives: a virginal conception (Luke 1:26-28) and "Jesus of the seed of David through Joseph" (Luke 3:23-38; Acts 2:30; 13:23). Lincoln (2013) therefore concludes:

\footnotetext{
${ }^{18}$ The reference to Mary as parthenos ("virgin") does not need to denote an unmarried woman, because in Greek thought "virginity did not depend on the presence of a hymen" (see Sissa 1990, 78-79, 170).
} 
The overall impression from the New Testament-its unified witness, one might say-is of dual fatherhood-human and divine. This makes it particularly significant that ... the two modes of presentation are combined in one of the witnesses, Luke-Acts. By holding together both the notion of virginal conception and the assumption that Joseph was Jesus' biological father, Luke reinforces the dialogical and polyphonic nature of scriptural truth about the significance of what God has done and is doing in Christ. (p. 250)

Theologically for Lincoln this "juxtaposition" provides a scripturally sound possibility for Christians to preserve the mystery of the incarnation and its accompanying doctrines without "the historically conditioned presentation of a virginal conception" $(2013,272,296)$.

\section{The Ethical Relevance of Jesus as both Vere Homo and Vere Deus}

The stories of the birth of Jesus precede the accounts of his resurrection in both Scripture and the Christian creeds. Yet, they should be understood only on the basis of Easter, rather than the other way around (Marxsen 1969, 169-170; cf. Ogden 1996, 249). These powerful narratives are classic in their own right. Over so many centuries they have articulated a confession of faith so story-like, so aesthetically beautiful that it is not nullified by the findings of the Jesus Seminar (see Funk 1998, 497-526) of which I was an active participant. Historically, the seminar members do not know whether Jesus of Nazareth was conceived while his mother, Mary, was engaged to Joseph. Viewed historically, ninety-six percent are certain that Mary did not become pregnant without having had sexual intercourse with a man. Fifty percent find Joseph to have possibly been the biological father of Jesus and ninety-seven percent that Mary was his biological mother. In a separate vote on the particulars of the genealogical record of Jesus in Matthew, the majority of the Jesus Seminar is uncertain whether Jacob was the father of Joseph, and therefore, whether Jesus was indirectly of Davidic descent. For eighty-five percent of the seminar members Joseph was the name of the man who adopted Jesus as his child. Four percent are convinced that Mary gave birth to Jesus as a result of either having been raped or seduced by an unknown man. Despite the absence of clear historical proof, twenty-nine percent deem it possible that 
Mary's pregnancy might have been the result of either rape or seduction. Almost all of the members (ninety-nine percent) are convinced that the reports in Matthew and Luke that Jesus was conceived by the Holy Spirit constitute not a "historical statement" but a "theological" one.

Against the background of these historical-critical opinions, Lincoln makes a contribution by re-interpreting Jesus's birth stories in terms of DNA. Commendable is his openness to diverse beliefs regarding Jesus's birth and identity as either conceived normally, according to modern biological science and knowledge of genetics, with complete human DNA, or conceived virginally, with the Y chromosome missing or, presumably, divinely supplied. According to him, the NT already bears witness to such tolerance. However, I do not see an inclination to such a "tolerance" in Luke-Acts. I would rather emphasise a Pauline influence on the concept of messianism and the notion "seed of David" in Luke. ${ }^{19}$ With regard to Matthew's account of Jesus's birth, I consider it a midrash on apocalypticmessianic themes and Moses's divine conception similar to that in PseudoPhilo. On the other hand, in Luke-Acts a similarity can be seen with Plutarch's stories of Alexander the Great (see Dungan and Cartlidge 1974, 7-8). In both Luke-Acts and Plutarch ancient biology and ancient biography are interwoven. The same can be said of Ovid's narrative of Perseus (in Metam.) and Seneca's jubilees of Hercules (Herc. fur. and Herc. Ot.; see Pratt 1939, 27).

In other words, in the NT there are two perspectives on Jesus's birth: that of virginal conception and that of kenosis. Traditionally, Paul and John were seen as representatives of the kenosis conceptualisation of Jesus's birth. However, I contend that John's idea is not that of kenosis, but that he had his own particular conceptualisation of the birth of Jesus. John's understanding formed the basis of creedal Christianity, which confesses the two natures of Jesus as simultaneously vere homo and vere Deus. The key text is John 1:14a: "the $\lambda$ ó $\gamma$ o $\varsigma$ became $\sigma \alpha ́ \rho \xi$ and we have

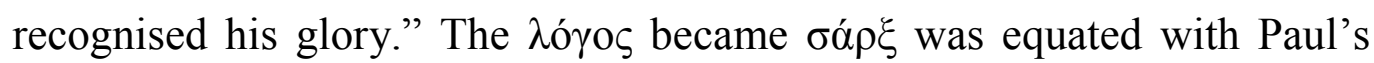
"the son who emptied himself of his godly status to become $\sigma \alpha ́ \rho \xi "$ "(Phil 2:7). ${ }^{20}$ This is kenosis Christology. However, when John says that the

\footnotetext{
${ }^{19}$ See pp. 38-39 above. To me, the NT indeed witnesses two incompatible views with regard to Jesus's birth which are to be found respectively in Matthew and Luke, on the one hand, and Paul and John, on the other hand.

${ }^{20}$ See Schleiermacher $(2008,40)$, who states it as follows: "In the Gospel of John the concepts Logos [Word] and Son of God are statements about the relationship of the historical Christ [geschichtlichen Christus] with us, as well as his origin." (my
} 


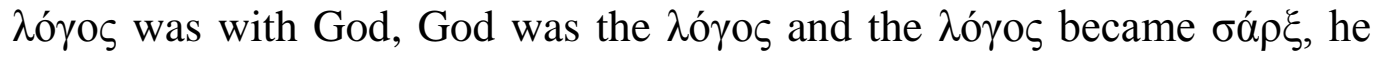
does not mean kenosis. Kenosis presupposes a sequence. For John, Jesus is simultaneously God and man who neither forfeits godly status nor $\sigma \alpha ́ \rho \xi$. In John, while seeing Jesus's birth as "natural" and not as a result of a "virginal conception," Jesus is most fully vere homo and vere Deus. This is the reason why I "categorised" the Johannine Prologue as part of the textual evidence that belongs to "creedal Christianity." The expression

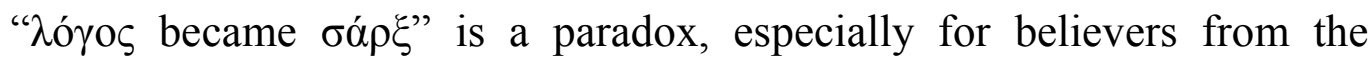
Israelite tradition and later gnostic-oriented believers who did not want to mix God and creation. According to them, God cannot be a human being. For gnostics the true God could not be identified with corrupt and transient creation. John's idea is, however, not a paradox, but rather an obstacle $(\sigma \kappa \alpha ́ v \delta \alpha \lambda \sigma v)$. The challenge for John is that believers should overcome the obstacle or the $\sigma \kappa \alpha ́ v \delta \alpha \lambda o v$. That is why he says in John 1:14 that they have

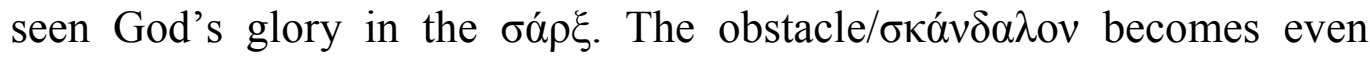
greater at the end of the Gospel of John when the divine glory is crucified. The challenge to see God as present in the one who was born human and was crucified as a humiliated human, is even greater.

Two misconceptions in theological discourse are: that the conceptualisation of the dual natures of Jesus is not biblical but is a creation of the confessions; that theologians who accept that Jesus was both vere homo and vere Deus regard historical Jesus research as irrelevant. Käsemann $(1979,36)$, for example, cannot understand how Bultmann can say that the historical Jesus is irrelevant for faith. He, with his New Quest, tried to show the relevance of historical Jesus research for the faith community. However, Bultmann does not claim that historical Jesus research is meaningless (cf. Labron 2011, 27). For Bultmann (1958), historical criticism is an imperative. The $\lambda$ ó ${ }^{\circ} \varsigma$ that became flesh did so in a very specific historical person-Jesus. Historical criticism is irrelevant only if exegetes do not also see the divine glory in the human being Jesus. ${ }^{21}$ Historiography as such only deals with corrupt transient data. Historical criticism is necessary to describe the life of the historical Jesus as far as that is possible. If exegetes should limit themselves to historical

translation of Im Johannesevangelium sind die Begriffe des Logos und des Sohn Gottes Aussagen über das Verhältnis des geschichtlichen Christus zu uns und dessen Herkunft.)

21 "Jesus is a human, historical person ... his work and destiny happened within world history and as such come under the scrutiny of the historian who can understand them as part of the nexus of history. Nevertheless, such detached historical inquiry cannot become aware of what God has wrought in Christ. ..." (Bultmann 1958, 80). 
criticism and the man of Galilee, then they cannot overcome the obstacle/ $\sigma \kappa \alpha ́ v \delta \alpha \lambda$ ov and cannot recognise the divine glory present in this world. God became human in this man from Galilee (Bultmann 1971, 65). Those who, like the gnostics, emphasise the godly and despise the human, also cannot overcome the obstacle. However, as Labron (2007) puts it:

In effect, if the humanity is a "disguise" then the paradox of [John] 1:14a is solved with glory and conversely, if the glory is a sham, then the humanity is the solution. Bultmann, however, keeps the paradoxical relationship ... [T] he Church in principle holds to the Chalcedonian position, as does Bultmann. (p. 14)

Creedal Christianity is therefore a legitimate continuity of one of the most prominent christological views in the NT, namely that of John: Jesus, vere homo and vere Deus. To see and believe that divine glory is present in the $\sigma \alpha ́ \rho \xi$ of Jesus is to acknowledge that God loves the cosmos and that humanness is important to God. Paul's kenosis theory contains the essence of this concept, but not the depth that is present in John. His formulation does not adequately express the simultaneity.

To summarise, in this article I argued that in the NT there are two contradictory views: divine conception on the one hand and natural birth on the other. However, in a mythological world such as that of the NT, the church fathers and the context in which the creeds of early Christianity originated, there is no dichotomy between the physical and the metaphysical. From a theological perspective it is impossible for modern readers of these ancient texts to discern whether Jesus was only human or only divine. For the exegete, however, on account of concrete textual evidence, the perspective of John and Paul on Jesus's origin cannot be reconciled with the miraculous birth stories found in Matthew and Luke. On the other hand, knowing that for the ancients there was no dichotomy between the physical and the metaphysical, it does not come as surprise that Ignatius harmonises these radically opposing viewpoints in his controversy with the "Gnostics." For the first time in the history of biblical interpretation, concrete textual evidence about the virginal conception (Luke-Matthew) of God's eternal son (Paul-John) could be indicated and became part of a broad creedal paradigm. Ignatius was responsible for combining mutually exclusive myths. Over against the "Gnostics" he aimed to emphasise that Jesus was truly human. In all the confessions that 
followed a similar trend can be discerned, namely the emphasis that Jesus was undoubtedly human.

The ancients' view of Jesus's birth has the consequence that Christian ethics is not an abstract ideology. It is based on the humanness and the humaneness of the Jesus of history.

The historical quest for Jesus's identity as both vere homo and vere Deus illuminates the gospel message of Jesus as the liberated one who liberated others. As the living symbol of God's unmediated presence amid humankind, Jesus set people free. As vere Deus, he still sets people free. This includes all people, irrespective of sexual orientation, gender, age, ethnicity, social, and religious affiliation. This is freedom from distorted relationships with oneself, with others, and with God.

The question as to the relationship between vere homo and vere Deus can never be answered definitively. The challenge is to find an answer for the immediate present: to live in the presence of God and in meaningful relationships with others.

For Schleiermacher $(1999,397)$ the two natures of Jesus manifest in a God-consciousness in his humanness. Similarly "God is present in all other human beings," though "to a far greater degree" in Jesus (ibid., 364). This is why Schleiermacher speaks of Jesus as both an Urbild and a Vorbild. According to Resch $(2012,26)$ this means that Jesus had the ability to impart God-consciousness to others. Christ-followers can participate in this God-consciousness (Clements 1987, 57) when they retell the stories of his birth in whatever genre, be it sermons, liturgical hymns, confessional creeds, poetry, film, novels, etcetera. Resch (2012) rephrases Schleiermacher as follows:

When the early disciples perceived the perfection of Christ, their own consciousness of God was awakened and developed. In turn, the proclamation of the sinless Christ by the first disciples had a similar effect on others, thus perpetuating the redemptive work of Christ through history. (p. 27)

In Schleiermacher's (2010) Weihnachtsfeier the "churchless" participant, Leonhardt, says:

This tradition, therefore, we shall want to maintain as it has been handed down to us, and the less surely we can explain wherein its marvellous power lies, the less eager we will be to change even the least detail in it. For me, at least, even the smallest features are 
full of meaning. Just as a child is the main object of our celebration, so it is also the children above all who elevate the festival and carry it forth-and through it Christianity itself ... This is my honest opinion, upon which I suggest we touch our glasses and empty them in a toast - a toast to an unending continuation of the Christmas festival. Furthermore, I am all the more certain of your compliance that I hope thereby to make up for and to wash away everything that may have seemed offensive to you in what I have said. (pp. 70-71)

So do I in this revisiting of the birth of Jesus as it was also my intent in my book Fatherless in Galilee: Jesus as Child of God (Van Aarde 2001; 2013).

\section{Bibliography}

Aland, B., and K., eds. [1981] 1992. Greek-English New Testament. 6th rev. ed. Novum Testamentum Graeca. 27th ed. Stuttgart: Deutsche Bibelgesellschaft.

Anker, J. 2008. Magical Realism and the Religious in Praying Mantis (orig. in Afrikaans). Tydskrif vir Letterkunde 45(2):5-19.

Archbishops' Council of the Church of England. [1662] [2000] 2015. Book of Common Prayer, Church of England. The Archbishops' Council, reproduced by permission of the Crown's Patentee. Cambridge: Cambridge University Press. Cited 03 September 2015. Online: justus.anglican.org/resources/bcp/ england.htm.

Aristotle. [384-322 BCE] 1942. On the Generation of Animals (Peri zōōn geneseōs). Edited by L. Peck. Cambridge, MA: Harvard University Press [LCL 366].

Barth, F. 1918. Die Hauptprobleme des Lebens Jesu: Eine geschichtliche Untersuchung. 5. Auflage. Gütersloh: Gütersloher Verlag.

Barth, K. [1923-1924] 1982. The Theology of Schleiermacher: Lectures at Göttingen, Winter Semester 1923/24. Translated by G. W. Bromiley. Grand Rapids: Eerdmans. [1927] 1982. Die christliche Dogmatik im Entwurf, Erster Band: Die Lehre vom Wortes Gottes. Prolegomena zur christliche Dogmatik. Edited by G. Sauter. Zürich: Theologischer Verlag. 1932-1970. Die kirchliche Dogmatik. Vols. I-IV. Zürich: EVZ Verlag. 1991. Göttingen Dogmatics: Instruction in the Christian Religion. Translated by G. W. Bromiley. Vol. 1. Grand Rapids: Eerdmans.

Brink, A. P. [2005] 2006. Praying Mantis. New York: Knopf Doubleday. . [1982] 2007. The Chain of Voices: A Novel. Naperville, IL: Sourcebooks Landmark.

Brown, H. [2005] 2016. André Brink Interview: "Sharpeville was a Terrible Shock." The Telegraph, 5 July 2016.

Bultmann, R. 1958. Jesus Christ and Mythology. New York: Charles Scriber's Sons. 
[1921] 1967. Die Geschichte der synoptischen Tradition. 5. Auflage. Edited

by G. Theissen and P. Vielhauer. Göttingen: Vandenhoeck \& Ruprecht.

. 1968. Theologie des Neuen Testaments. 6. Auflage. Tübingen: J. C. B. Mohr

(Paul Siebeck) [Neue Theologische Grundrisse].

1971. The Gospel of John: A Commentary. Translated by G. R. Beasley-

Murray. Edited by R. W. N. Hoare and J. K. Riches. Philadelphia: Westminster.

1972. The History of the Synoptic Tradition. Blackwell: Wiley.

[1951] 1974. Theology of the New Testament. Vol. One. Waco: Baylor

University Press.

1985. The Second Letter to the Corinthians. Minneapolis: Augsburg.

Burchard, C. 1965. Untersuchungen zu Joseph und Aseneth: ÜberlieferungOrtbestimmung. Tübingen: Mohr [WUNT 8].

Chesnutt, R. D. 1996. From Text to Context: The Social Matrix of Joseph and Aseneth. Pages 285-302 in SBL 1996 Seminar Papers. Atlanta: Scholars Press [SBLSP 35].

Dean-Jones, L. 1994. Women's Bodies in Classical Greek Science. Oxford: Oxford University Press.

Duling, D. C. 2012. A Marginal Scribe: Studies in the Gospel of Matthew in a Social Scientific Perspective. Eugene: Wipf \& Stock (Cascade Books) [Matrix: The Bible in Mediterranean Context 7].

Dungan, D. I., and D. R. Cartlidge. 1974. The Birth of Alexander the Great (Plutarch, Parallel lives, Alexander 2.1-3.2). Translated by D. R. Cartlidge. Pages 7-8 in Sourcebook of Texts for the Comparative Study of the Gospels. 4th ed. Edited by D. I. Dungan and D. R. Cartlidge. Missoula: Scholars Press [Corrected Sources for Biblical Study 1].

Clements, K. 1987. Friedrich Schleiermacher: Pioneer of Modern Theology. London: Collins.

Ernst, J. 1989. Johannes der Täufer: Interpretation, Geschichte, Wirkungsgeschichte. Berlin: de Gruyter.

Freed, E. D. 2001. The Stories of Jesus'Birth: A Critical Introduction. Sheffield: Sheffield Academic.

Funk, R. W. 1996. Honest to Jesus: Jesus for a New Millennium. San Francisco: HarperSanFrancisco.

Funk, R. W. (and The Jesus Seminar) 1998. The Acts of Jesus: What Did Jesus Really Do? San Francisco: HarperSanFrancisco.

Galenus, Aelius (Claudius). [ca. 129-216 CE] 2003. ГА $\Lambda$ HNOY ПЕPI KYOYMEN $\Omega N$ $\triangle \mathrm{IA} \Lambda \mathrm{A} \Sigma \mathrm{E} \Omega \Sigma$ / Galeni. De Foetuum Formation / Galen über die Ausformung der Keimlinge. Pages 51-173 in Corpus Medicorum Graecorum, 5.3.3. Herausgegeben von der Berlin Brandenburgischen Akademie der Wissenschaften. Edited by D. Nickel. Berlin: de Gruyter. Cited 8 July 2016. Online: https://www.degruyter.com/view/serial/234885/; http://www.bbaw.de/ bbaw/Forschung/Forschungsprojekte/cmg/de/Ueberblick.

Hahn, F. [2002] 2005. Theologie des Neuen Testaments, Band 1: Die Vielfalt des Neuen Testaments: Theologiegeschichte des Urchristentums. 2., durchgesehene und um ein Sachregister ergänzte Auflage. Tübingen: Mohr Siebeck. 
Harrington, D. J. 1985. Pseudo-Philo: A New Translation and Introduction. Pages 297377 in The Old Testament Pseudepigrapha. Vol. 2. Edited by J. H. Charlesworth. Garden City: Doubleday.

Harris, M. J. [1992] 2008. Jesus as God: The New Testament Use of "Theos" in Reference to Jesus. Grand Rapids: Baker.

Harrison, M. John. 2016. Suspended between Heaven and Hell. The Telegraph, 5 July 2016.

Horsley, R. A. 1989. The Liberation of Christmas: The Infancy Narratives in Social Context. New York: Crossroad.

Ignatius of Antioch. [110 CE] 1994. Epistle to the Ephesians 19:1, in Ante-Nicene Fathers, vol. 1. Edited by A. R. Roberts and J. Donaldson. Peabody: Hendrickson. Revised and edited for New Advent by Kevin Knight, 2009. Buffalo, NY: Christian Literature Publishing Co. Cited 3 September 2015. Online: http://www.newadvent.org/fathers/0109.htm.

Ignatius of Antioch. [110 CE] [1885] 2009. Epistle to the Smyrnaeans in Ante-Nicene Fathers, vol. 1. Edited by A. R. Roberts and J. Donaldson. Peabody: Hendrickson. Revised and edited for New Advent by Kevin Knight, 2009. Buffalo, NY: Christian Literature Publishing Co. Cited 3 September 2015. Online: http://www.newadvent.org/fathers/0109.htm.

Jewett, R. 2007. Romans: A Commentary. Minneapolis: Fortress [Hermeneia].

John of Damascus. [ca. 675-749] [1958] 1999. (Exact Exposition of) The Orthodox Faith/ De Fide Orthodoxa in Saint John of Damascus. Translated by Frederic H. Chase. Washington, DC: Catholic University of America Press [The Fathers of the Church 37]. Cited 19 September. Online: http://trove.nla.gov.au/ version/209060226.

Käsemann, E. 1979. New Testament Questions of Today. Translated by W. J. Montague. Philadelphia: Fortress.

Kee, H. C. 1990. What Can We Know About Jesus? Cambridge: Cambridge University Press.

Kessler, G. 2009. Conceiving Israel: The Fetus in Rabbinic Narratives. Philadelphia: University of Pennsylvania Press.

Köstenberger, A. J., S. Kellum, and C. L. Quarles. 2009. The Cradle, the Cross, and the Crown: An Introduction to the New Testament. Nashville: B\&H Publishing Group.

Labron, T. 2011. Bultmann Unlocked. London: T\&T Clark.

Laqueur, T. 1990. Making Sex: Body and Gender from the Greeks to Freud. Cambridge, MA: Harvard University Press.

Lenta, M. 2010. A Chain of Voices and Unconfessed: Novels of Slavery in the 1980s and in the Present Day. Journal of Literary Studies 26(1):95-110. doi: 10.1080/02564710903495529

Lincoln, A. T. 2013. Born of a Virgin? Reconceiving Jesus in the Bible, Tradition, and Theology. Grand Rapids: Eerdmans.

Lincoln, A. 2014. How Babies Were Made in Jesus' Time. BAR 49(6):42-49. 
Lourens, S. T. 2009. Writing History: National Identity in André Brink's Post-Apartheid Fiction. Ph.D. dissertation, Amsterdam School for Cultural Analysis (ASCA), University of Amsterdam. Cited 5 July 2016. Online: http://hdl.handle.net/ $11245 / 2.70758$.

Oseka, M. 2015. An Equilibrium: Schleiermacher's Insights into the Confessional Subscription in Its Historical Setting. Juan Dao: A Journal of Bible \& Theology 43:33-72.

Malherbe, V. C. 1979. The Life and Times of Cupido Kakkerlak. The Journal of African History 20(3):365-378.

Marxsen, W. 1969. Der Exeget als Theologe: Vorträge zum Neuen Testament. 2d ed. Gütersloh: Gütersloher Verlagshaus.

Miller, R. J. 2003. Born Divine: The Births of Jesus and Other Sons of God. Santa Rosa, CA: Polebridge.

Ogden, S. M. 1996. Doing Theology Today. Valley Forge, PA: Trinity.

Ovid. [8 CE] 1997. Metamorphoses, Book 1-15. Edited with introduction and commentary by A. S. Anderson. From 6th ed. [B.G. Teubner, Stuttgart]. Norman: University of Oklahoma Press.

Peacocke, A. 2000. DNA of our DNA. Pages 59-70 in The Birth of Jesus: Biblical and Theological Reflection. Edited by G. J. Brooke. Edinburgh: T\&T Clark.

Pearson, L. 2003. Schleiermacher and the Christologies behind Chalcedon. HTR 96(3):349-367.

Philonenko, M. 1968. Joseph et Aseneth: Introduction, texte critique, traduction et notes. Leiden: Brill [SPB 13].

Pratt, N. T. 1939. Dramatic Suspense in Seneca and in his Greek Precursors. Princeton: Princeton University Press.

Resch, D. 2012. Barth's Interpretation of the Virgin Birth: A Sign of Mystery. Burlington: Ashgate [Barth Studies].

Rose, C. B. 2005. The Parthians in Augustan Rome. American Journal of Archaeology 109(1):21-75. doi: 10.3764/aja.109.1.27-28

Schleiermacher, F. [1806] [1826] 2010. Christmas Eve Celebration: A Dialogue. Translated by T. N. Tice. Eugene: Cascade Books.

Schleiermacher, F. D. E. [1819] [1864] 1997. The Life of Jesus. Edited by J. C. Verheyden. Mifflintown, PA: Sigler. .1821-1822. Die christliche Glaube nach den Grundsätzen der evangelische Kirche im Zusammenhang dargestelt. Vol. 1-2. Berlin: Reimer.

. [1821-1822] [1830-1831] 1999. The Christian Faith. Translated by H. R. Mackintosh and J. S. Stewart. Edinburgh: T\&T Clark.

[1893] 2008. Das Wesen und die Bedeutung der besonderen Offenbarung in Schleiermachers Glaubenslehre: Letzter Teil. Edited by M. Schulze and P. Jenke (digitised). Princeton: Princeton University.

Schönborn, C. C. [2002] [2004] 2010. God Sent His Son: A Contemporary Christology. San Francisco: Ignatius Press.

Schweitzer, E. [1964] 1985. Sárx [flesh, body], sarkikós [fleshly, earthly], sárkinos [fleshly, fleshy]: The Greek World. Pages 1001-1007 in Theological Dictionary of the New Testament: Abridged in One Volume. Edited by G. F. Bromiley. Grand Rapids: Eerdmans. 
Sissa, G. [1987] 1990. Greek Virginity. Translated by A. Goldhammer. Cambridge, MA: Harvard University Press.

Standartinger, A. 1995. Das Frauenbild im Judentum der hellenistischen Zeit: Ein Beitrag anhand von "Joseph \& Aseneth." Leiden: Brill [Arbeiten zur Geschichte des Antiken Judentums und des Urchristentums]. . 1996. From Fictional Text to Socio-Historical Context: Some Considerations from a Textcritical Perspective on Joseph and Aseneth. Pages 303-317 in SBL 1996 Seminar Papers. Atlanta: Scholars Press [SBLSP 35].

Thombly, C. C. 2015. Perichoresis and Personhood: God, Christ, and Salvation in John of Damascus. Foreword by Myk Habets. Eugene: Wipf \& Stock.

Tice, T. N. [1990] 2011. Church History: On Viewing Christianity Historically. Pages 58-60 in Brief Outline of Theology as a Field of Study. F. Schleiermacher [1811] [1830] [1990] 2011. 3d ed. Revised translation of the 1811 and 1830 editions, with essays and notes by T. N. Tice. Louisville: Westminster John Knox.

Van Aarde, A. G. 1998. Jesus' Father: The Quest for the Historical Joseph. HTS Teologiese / Theological Studies 54(1\&2):315-333. 2001. Fatherless in Galilee: Jesus as Child of God. Harrisburg: Trinity. 2003. Die ou-Kersaandgesprek van Friedrich Schleiermacher in Afrikaans: Agtergrond, vertaling en hermeneutiek. HTS Teologiese/Theological Studies 59:545-568. 2004. Social Identity, Status Envy, and Jesus as Fatherless Child. Pages $223-$ 236 in Psychology and the Bible: A New Way to Read the Scriptures. Vol. 4: From Christ to Jesus. Edited by J. H. Ellens and W. G. Rollins. Westport, CT: Praeger. . 2013. Fatherless in Galilee: 'n Outobiografiese refleksie. Verbum et Ecclesia 34(2). Art. \#856, 8 pages. http://dx.doi.org/10.4102/ve.v34i2.856 2014. A Commemoration of the Legacy of Rudolf Bultmann, Born 130 Years Ago. Studia Historiae Ecclesiasticae 40(4):251-271.

. 2015. Progress in Psychological Biblical Criticism. Pastoral Psychology 64:481. doi: 10/1007/s11089-014-0636-y

Van der Horst, P. W. 1990. Sarah's Seminal Emission: Hebrews 11:11 in the Light of Ancient Embryology. Pages 287-302 in Greek, Romans and Christian Essays in Honor of Abraham Malherbe. Edited by E. Ferguson, A. J. Malherbe, D. J. Balch, and W. A. Meeks. Minneapolis: Fortress.

andries.vanaarde@up.ac.za

Private Bag X20, Hatfield 0028, Pretoria, South Africa 